Article

\title{
Coordination Complex Formation and Redox Properties of Kynurenic and Xanthurenic Acid Can Affect Brain Tissue Homeodynamics
}

\author{
Lenka Kubicova ${ }^{1}$, Franz Hadacek ${ }^{2}$, Gert Bachmann ${ }^{1}{ }^{1}$, Wolfram Weckwerth ${ }^{1,3}$ and \\ Vladimir Chobot $1, *$ (D) \\ 1 Division of Molecular Systems Biology, Department of Ecogenomics and Systems Biology, Faculty of Life \\ Sciences, University of Vienna, Althanstrasse 14, A-1090 Vienna, Austria; lenka.kubicova@univie.ac.at (L.K.); \\ gert.bachmann@univie.ac.at (G.B.); wolfram.weckwerth@univie.ac.at (W.W.) \\ 2 Department of Plant Biochemistry, Albrecht-von-Haller Institut, Georg-August-Universität Göttingen, \\ Justus-von-Liebig-Weg 11, D-37077 Göttingen, Germany; franz.hadacek@biologie.uni-goettingen.de \\ 3 Vienna Metabolomics Center (VIME), University of Vienna, Althanstrasse 14, 1090 Vienna, Austria \\ * Correspondence: vladimir.chobot@univie.ac.at; Tel.: +43-1-4277-76551
}

Received: 13 September 2019; Accepted: 8 October 2019; Published: 11 October 2019

\begin{abstract}
Reactive oxygen species (ROS) are known for their participation in various physiological and pathological processes in organisms, including ageing or degeneration. Kynurenine pathway metabolites, such as kynurenic (KYNA) or xanthurenic (XA) acid, can affect neurodegenerative diseases due to their ROS scavenging and Fe ion coordination complex formation but insights are still incomplete. Therefore, we investigated the formation and antioxidant capabilities of KYNAand XA-Fe complexes by nano-electrospray-mass spectrometry, differential pulse voltammetry, deoxyribose degradation and $\mathrm{Fe}^{\mathrm{II}}$ autoxidation assays. XA formed coordination complexes with $\mathrm{Fe}^{\mathrm{II}}$ or Fe${ }^{\mathrm{III}}$ ions and was an effective antioxidant. By contrast, only Fe ${ }^{\mathrm{II}}-\mathrm{KYNA}$ complexes could be detected. Moreover, KYNA showed no antioxidant effects in the $\mathrm{FeCl}_{3} /$ ascorbic acid deoxyribose degradation assay variant and only negligible activities in the $\mathrm{Fe}^{\mathrm{II}}$ autoxidation assay. Coordination complexes of Fe ions with KYNA probably stabilize KYNA in its keto tautomer form. Nevertheless, both KYNA and XA exhibited sufficient antioxidant activities in some of the employed assay variants. The results provide evidence that both have the potential to alleviate neurodegenerative diseases by helping to maintain tissue redox homeodynamics.
\end{abstract}

Keywords: Alzheimer's disease; antioxidant; Fenton reaction; hydroxyl radical; iron chelates; kynurenines; neurodegeneration; Parkinsonism; reactive oxygen species

\section{Introduction}

Reactive oxygen species (ROS) are inherent to many cellular signal cascades in physiological and also pathological organismic processes [1,2] and cell reproduction [3]. Therefore, ROS concentration control is one of the key requirements that constrain efficient functioning of enzymatic and non-enzymatic systems in aerobic organisms [1,4]. The tryptophan metabolites kynurenic (KYNA) and xanthurenic (XA) acid represent low-molecular-weight components of the redox homeodynamics control system (Figure 1) [5].

KYNA and XA are kynurenine pathway-derived quinolines that, similarly to other kynurenines, can affect physiological and pathological processes of the central nervous, immune and vascular systems [6-9]. In general, KYNA and XA seem to play an important role in the mammalian nervous system, of which complete understanding is still lacking $[6,10]$ despite KYNA's reputation as a neuroprotective agent and an endogenous antioxidant $[6,11]$. Pyridoxine (vitamin $\mathrm{B}_{6}$ ) deficiency 
increases the concentrations of both acids in the brain tissue [12]. Contrary to KYNA, XA is able to penetrate the blood-brain barrier (BBB). Therefore, XA can be accumulated in the brain tissue $(1 \mu \mathrm{M})$, either by endogenous biosynthesis or transport through the BBB [13]. The brain concentrations of KYNA are relatively low, about $150 \mathrm{nM}$ [14]. However, brain concentrations of both acids can fluctuate depending on the metabolic situations $[13,15]$. Although KYNA penetrates only poorly through the BBB [11], exogenous KYNA, as a constituent of vegetables (e.g., potatoes) [16], may affect brain functions indirectly via positive effects on the gut-brain axis $[17,18]$. Furthermore, KYNA and its selected chemical derivatives can prolong longevity of bdelloid rotifers significantly [19].

By forming coordination complexes with transition metals, XA might affect degenerative diseases [5]. These metals, e.g., iron, accumulate in the brain. Ageing, neurodegenerative diseases in general and specifically damage of the blood-brain barrier can contribute to this process $[20,21]$. In healthy tissues, Fe ions are usually liganded by storage molecules. However, "poorly liganded" Fe ions are able to catalyze various chemical reactions that generate reactive oxygen species (ROS), especially cytotoxic hydroxyl radicals. In high concentrations, these ROS disturb the cellular redox homeodynamics and can trigger various pathological processes [21-23]. For example, the iron concentrations in senile plaques in brains of patients suffering from Alzheimer's disease can increase up to $0.9 \mathrm{mM}$ compared to the healthy controls of $0.3 \mathrm{mM}$ [24].

Since KYNA and XA are phenolic molecules, they possess reducing capabilities that can affect ROS concentrations. Albeit that numerous studies have explored the coordination complex formation properties of KYNA and XA as well as their ROS scavenging activities, the reported results make it difficult to draw consistent conclusions. KYNA is a known antioxidant [5,25]. However, Minakana et al. found no antioxidant effects of KYNA in reaction mixtures with liver microsomes [26]. Furthermore, KYNA appeared to be weakly liganded by iron due to its keto-enol tautomery [26]. Similarly, XA also showed inconsistent results in terms of antioxidant activity. XA inhibited lipid peroxidation and protected NADP-isocitrate dehydrogenase against its deactivation by ROS [27]; it decreased oxidative damage of DNA [28]. Conversely, XA promoted oxidative deactivation of aconitase [29].

Therefore, in attempts to study the interplay of reducing ability, antioxidant effects and coordination complex formation of KYNA and XA with iron, this study investigated the coordination complex formation by nano-ESI-MS (nano-electrospray ionization-mass spectrometry). The changes in redox activity of the central atom and the ligands were characterized by differential pulse voltammetry, deoxyribose degradation and $\mathrm{Fe}^{\mathrm{II}}$ autoxidation assays. This methodological approach was successful to explore ROS scavenging and coordination complex formation of other kynurenines with iron, such as anthranilic, 3-hydroxyanthranilic [30] and quinolinic acid [31,32].

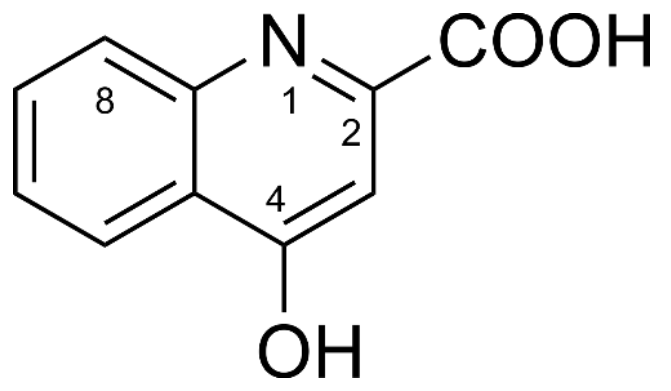

(a)

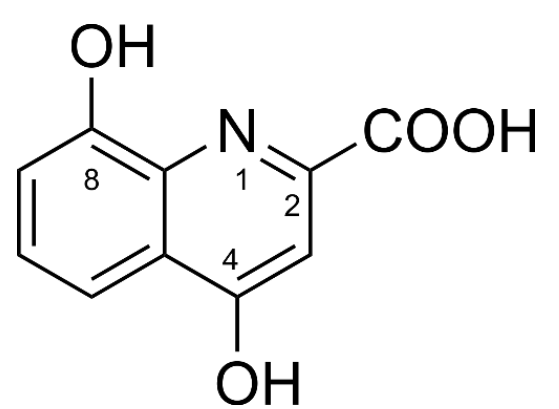

(b)

Figure 1. Chemical structures of (a) kynurenic acid and (b) xanthurenic acid.

\section{Materials and Methods}

\subsection{Chemicals}

All used chemicals were purchased from Sigma-Aldrich (Schnelldorf, Germany). Water was of Milli-Q quality (Milli-Q Advantage A10 System, Milllipore SAS, Molsheim, France). 


\subsection{Mass Spectrometry}

Direct infusion nano-electrospray ionization mass spectrometry was carried out in positive ionization mode on a Thermo Electron LTQ-Orbitrap XL mass spectrometer equipped with a nano electrospray ion source (ThermoFisher Scientific, Bremen, Germany) and operated under Xcalibur software 2.2 (ThermoFisher Scientific, Bremen, Germany) as described by Kubicova et al. [32]. Theoretical masses and characteristic iron isotopic patterns were calculated by Xcalibur software 2.2 (ThermoFisher Scientific, Bremen, Germany). The mass spectra were recorded for various metal-to-ligand ratios $(2: 1,1: 1,1: 2$ and 1:4).

\subsection{Differential Pulse Voltammetry}

The detailed procedures have been described previously [30]. For records of differential pulse voltammograms, a three-electrode system, $\mu$ Autolab PGSTAT type III (EcoChemie Inc., Utrecht, The Netherlands), was used. A glassy carbon electrode ( $3 \mathrm{~mm}$ in diameter) served as a working electrode, a platinum wire as a counter electrode, and $\mathrm{Ag} / \mathrm{AgCl}(3 \mathrm{M}$ aqueous solution of $\mathrm{KCl}$ ) as a reference electrode. The electrochemical experiments were performed using the following parameters: The effective scan rate of the voltammetry was set to $21 \mathrm{mV} / \mathrm{s}$, modulation time to $0.05 \mathrm{~s}$, modulation amplitude to $25 \mathrm{mV}$, and the scan potential was from -0.500 to $+1.350 \mathrm{~V}$. The solution of supporting electrolyte was degassed buffer (0.1 M phosphate buffer $\mathrm{pH} 7.4$; buffer ionic strength $1 \mathrm{M}$, adjusted by $\left.\mathrm{K}_{2} \mathrm{SO}_{4}\right)$. The measuring atmosphere was argon. Several metal-to-ligand ratios were analyzed (1:1, 1:2, $1: 3$ and 1:4).

\subsection{Deoxyribose Degradation Assay}

The procedures of deoxyribose degradation assay were performed as described in detail elsewhere [33]. The used buffer was aqueous solutions of $\mathrm{KH}_{2} \mathrm{PO}_{4} / \mathrm{KOH}(30 \mathrm{mM}, \mathrm{pH}$ 7.4). The assay is carried out in eight variants; four of them without addition of ethylenediaminetetraacetic acid (EDTA) and four of them in the presence of EDTA as Fe chelator. The basic assay variants are represented by $\mathrm{H}_{2} \mathrm{O}_{2} / \mathrm{FeCl}_{3}$ /ascorbic acid or $\mathrm{H}_{2} \mathrm{O}_{2} / \mathrm{Fe}^{\mathrm{III}}$ EDTA/ascorbic acid variants, the other assay variants omitted $\mathrm{H}_{2} \mathrm{O}_{2}$ and/or ascorbic acid. The $\mathrm{H}_{2} \mathrm{O}_{2} / \mathrm{FeCl}_{3}$ /ascorbic acid or $\mathrm{H}_{2} \mathrm{O}_{2} / \mathrm{Fe}^{\mathrm{III}}$ EDTA/ascorbic acid reaction mixtures served as the positive control, represented 100\% thiobarbituric acid reactive species (TBARS) detection in all variants and also served as the comparative standard for each experiment. Blanks contained the full reaction mixtures, except for 2-deoxyribose, and were determined in each experiment. Experiments were performed in triplicate. The temperature during incubation was $27^{\circ} \mathrm{C}$. Variants containing $\mathrm{H}_{2} \mathrm{O}_{2}$ were evaluated after $1 \mathrm{~h}$; variants without $\mathrm{H}_{2} \mathrm{O}_{2}$ were evaluated after $16 \mathrm{~h}$ of incubation.

\subsection{Fe Autoxidation Assay}

The procedures and reaction mechanisms were published by Chobot et al. [34]. The aqueous solutions of $\mathrm{KH}_{2} \mathrm{PO}_{4} / \mathrm{KOH}$ (30 mM, pH 7.4) were used as the buffer. The reaction mixtures contained a test substance diluted serially, 2-deoxyribose and $\mathrm{FeSO}_{4}$. Blanks contained the full reaction mixtures, except for 2-deoxyribose. Reaction mixtures were incubated at $27{ }^{\circ} \mathrm{C}$ for $16 \mathrm{~h}$. Thiobarbituric acid reactive species (TBARS) were determined photometrically with a microplate reader (Tecan Infinite M200, Männedorf, Switzerland) at $532 \mathrm{~nm}$. Experiments were performed in triplicate. Reaction mixtures lacking the test compound served as the positive control (100\% TBARS).

\section{Results}

\subsection{Mass Spectrometry}

KYNA and XA formed coordination complexes with Fe $\mathrm{II}^{\mathrm{II}}$ ions (Tables 1-3 and Figure 2). However, only XA entered coordination complexes with $\mathrm{Fe}^{\mathrm{III}}$ ions. The figures and tables present the results of reaction solutions with the adjusted molar ratio of ligand to Fe ions of 2:1 and assumed $m / z$ values for 
coordination complexes of the isotope ${ }^{56} \mathrm{Fe}$. The typical iron isotopic pattern $\left({ }^{54} \mathrm{Fe} 5.8 \%,{ }^{56} \mathrm{Fe} 91.7 \%\right.$, ${ }^{57} \mathrm{Fe} 2.2 \%$, and ${ }^{58} \mathrm{Fe} 0.3 \%$ ) corresponded with the pattern of identified coordination complexes.

Table 1. The main signals of ${ }^{56} \mathrm{Fe}-\mathrm{KYNA}$ coordination complexes in the solutions of KYNA with Fe $\mathrm{II}^{\mathrm{II}}$ analyzed by nano-ESI-MS; a positive ionization mode.

\begin{tabular}{ccccc}
\hline Composition & Formula & $\begin{array}{c}\mathbf{m} / \mathbf{z} \\
\text { Calculated }\end{array}$ & $\begin{array}{c}\mathbf{m} / \mathbf{z} \\
\text { Found }\end{array}$ & $\Delta$ [ppm] \\
\hline$[\mathrm{KYNA}+\mathrm{H}]^{+}$ & {$\left[\mathrm{C}_{10} \mathrm{H}_{8} \mathrm{NO}_{3}\right]^{+}$} & 190.0499 & 190.0499 & 0.13 \\
{$[\mathrm{KYNA}+\mathrm{Na}]^{+}$} & {$\left[\mathrm{C}_{10} \mathrm{H}_{7} \mathrm{NNaO}_{3}\right]^{+}$} & 212.0318 & 212.0319 & 0.42 \\
{$\left[\mathrm{KYNA}+\mathrm{Fe}^{\mathrm{II}}+\mathrm{H}_{2} \mathrm{O}-\mathrm{H}\right]^{+}$} & {$\left[\mathrm{C}_{10} \mathrm{H}_{8} \mathrm{FeNO}_{4}\right]^{+}$} & 261.9797 & 261.9797 & 0.01 \\
{$\left[\mathrm{KYNA}+\mathrm{Fe}^{\mathrm{II}}+\mathrm{MeOH}-\mathrm{H}\right]^{+}$} & {$\left[\mathrm{C}_{11} \mathrm{H}_{10} \mathrm{FeNO}_{4}\right]^{+}$} & 275.9954 & 275.9953 & -0.10 \\
{$\left[2 \mathrm{KYNA}+\mathrm{Fe}^{\mathrm{II}}-\mathrm{H}\right]^{+}$} & {$\left[\mathrm{C}_{20} \mathrm{H}_{13} \mathrm{FeN}_{2} \mathrm{O}_{6}\right]^{+}$} & 433.0118 & 433.0117 & -0.04 \\
{$\left[3 \mathrm{KYNA}+\mathrm{Fe}^{\mathrm{II}}-\mathrm{H}\right]^{+}$} & {$\left[\mathrm{C}_{30} \mathrm{H}_{20} \mathrm{FeN}_{3} \mathrm{O}_{9}\right]^{+}$} & 622.0543 & 622.0544 & 0.02 \\
{$\left[3 \mathrm{KYNA}+2 \mathrm{Fe}^{\mathrm{II}}-3 \mathrm{H}\right]^{+}$} & {$\left[\mathrm{C}_{30} \mathrm{H}_{18} \mathrm{Fe}_{2} \mathrm{~N}_{3} \mathrm{O}_{9}\right]^{+}$} & 675.9736 & 675.9736 & -0.07 \\
\hline
\end{tabular}

Table 2. The main signals of ${ }^{56} \mathrm{Fe}-\mathrm{XA}$ coordination complexes in the solutions of XA with Fe ${ }^{\mathrm{II}}$ analyzed by nano-ESI-MS; a positive ionization mode.

\begin{tabular}{ccccc}
\hline Composition & Formula & $\begin{array}{c}\mathbf{m} / \mathbf{z} \\
\text { Calculated }\end{array}$ & $\begin{array}{c}\mathbf{m} / \mathbf{z} \\
\text { Found }\end{array}$ & $\Delta$ [ppm] \\
\hline$[\mathrm{XA}+\mathrm{H}]^{+}$ & {$\left[\mathrm{C}_{10} \mathrm{H}_{8} \mathrm{NO}_{4}\right]^{+}$} & 206.0448 & 206.0449 & 0.45 \\
{$[\mathrm{XA}+\mathrm{Na}]^{+}$} & {$\left[\mathrm{C}_{10} \mathrm{H}_{7} \mathrm{NNaO}_{4}\right]^{+}$} & 228.0267 & 228.0268 & 0.41 \\
{$\left[2 \mathrm{XA}+\mathrm{Fe}{ }^{\mathrm{III}}-\mathrm{H}\right]^{2+}$} & {$\left[\mathrm{C}_{20} \mathrm{H}_{14} \mathrm{FeN}_{2} \mathrm{O}_{8}\right]^{2+}$} & 233.0044 & 233.0045 & 0.18 \\
{$\left[\mathrm{XA}+\mathrm{Fe} \mathrm{II}_{2}+\mathrm{H}_{2} \mathrm{O}-\mathrm{H}\right]^{+}$} & {$\left[\mathrm{C}_{10} \mathrm{H}_{8} \mathrm{FeNO}_{5}\right]^{+}$} & 277.9746 & 277.9747 & 0.08 \\
{$\left[\mathrm{XA}+\mathrm{Fe}^{\mathrm{II}}+\mathrm{MeOH}-\mathrm{H}\right]^{+}$} & {$\left[\mathrm{C}_{11} \mathrm{H}_{10} \mathrm{FeNO}_{5}\right]^{+}$} & 291.9903 & 291.9902 & -0.34 \\
{$\left[\mathrm{XA}+\mathrm{Fe}^{\mathrm{III}}+2 \mathrm{MeOH}-2 \mathrm{H}\right]^{+}$} & {$\left[\mathrm{C}_{12} \mathrm{H}_{13} \mathrm{FeNO}_{6}\right]^{+}$} & 323.0087 & 323.0085 & -0.48 \\
{$\left[2 \mathrm{XA}+\mathrm{Fe}^{\mathrm{II}}-\mathrm{H}\right]^{+}$} & {$\left[\mathrm{C}_{20} \mathrm{H}_{13} \mathrm{FeN}_{2} \mathrm{O}_{8}\right]^{+}$} & 465.0016 & 465.0017 & 0.16 \\
{$\left[2 \mathrm{XA}+\mathrm{Fe} \mathrm{II}_{+}+\mathrm{Na}-2 \mathrm{H}\right]^{+}$} & {$\left[\mathrm{C}_{20} \mathrm{H}_{12} \mathrm{FeN}_{2} \mathrm{NaO}_{8}\right]^{+}$} & 486.9835 & 486.9836 & 0.23 \\
{$\left[2 \mathrm{XA}+\mathrm{Fe}^{\mathrm{II}}+\mathrm{Fe}{ }^{\mathrm{II}}+\mathrm{MeOH}-4 \mathrm{H}\right]^{+}$} & {$\left[\mathrm{C}_{21} \mathrm{H}_{14} \mathrm{Fe}_{2} \mathrm{~N}_{2} \mathrm{O}_{9}\right]^{+}$} & 549.9393 & 549.9393 & 0.10 \\
\hline
\end{tabular}

Table 3. The main signals of ${ }^{56} \mathrm{Fe}-\mathrm{XA}$ coordination complexes in the solutions of XA with Fe $\mathrm{F}^{\mathrm{III}}$ analyzed by nano-ESI-MS; a positive ionization mode.

\begin{tabular}{ccccc}
\hline Composition & Formula & $\begin{array}{c}\mathbf{m} / \mathbf{z} \\
\text { Calculated }\end{array}$ & $\begin{array}{c}\mathbf{m} / \mathbf{z} \\
\text { Found }\end{array}$ & $\Delta$ [ppm] \\
\hline$[\mathrm{XA}+\mathrm{H}]^{+}$ & {$\left[\mathrm{C}_{10} \mathrm{H}_{8} \mathrm{NO}_{4}\right]^{+}$} & 206.0448 & 206.0449 & 0.45 \\
{$[\mathrm{XA}+\mathrm{Na}]^{+}$} & {$\left[\mathrm{C}_{10} \mathrm{H}_{7} \mathrm{NNaO}_{4}\right]^{+}$} & 228.0267 & 228.0269 & 0.82 \\
{$\left[\mathrm{XA}+\mathrm{Fe}{ }^{\mathrm{III}}+\mathrm{MeOH}-2 \mathrm{H}\right]^{+}$} & {$\left[\mathrm{C}_{11} \mathrm{H}_{9} \mathrm{FeNO}_{5}\right]^{+}$} & 290.9825 & 290.9825 & -0.05 \\
{$\left[\mathrm{XA}+\mathrm{Fe}{ }^{\mathrm{III}}+\mathrm{MeOH}+\mathrm{H}{ }_{2} \mathrm{O}-2 \mathrm{H}\right]^{+}$} & {$\left[\mathrm{C}_{11} \mathrm{H}_{11} \mathrm{FeNO}_{6}\right]^{+}$} & 308.9930 & 308.9931 & 0.16 \\
{$\left[\mathrm{XA}+\mathrm{Fe} \mathrm{III}_{+2 \mathrm{MeOH}-2 \mathrm{H}]^{+}}\right.$} & {$\left[\mathrm{C}_{12} \mathrm{H}_{13} \mathrm{FeNO}_{6}\right]^{+}$} & 323.0087 & 323.0088 & 0.24 \\
{$\left[3 \mathrm{XA}+2 \mathrm{Fe} \mathrm{Fe}_{-} 4 \mathrm{H}\right]^{2+}$} & {$\left[\mathrm{C}_{30} \mathrm{H}_{17} \mathrm{O}_{12} \mathrm{~N}_{3} \mathrm{Fe}_{2}\right]^{2+}$} & 361.4750 & 361.4750 & -0.01 \\
{$\left[2 \mathrm{XA}+\mathrm{Fe}^{\mathrm{III}}-2 \mathrm{H}\right]^{+}$} & {$\left[\mathrm{C}_{20} \mathrm{H}_{12} \mathrm{FeN}_{2} \mathrm{O}_{8}\right]^{+}$} & 463.9938 & 463.9938 & 0.16 \\
{$\left[2 \mathrm{XA}+2 \mathrm{Fe}{ }^{\mathrm{III}}+\mathrm{MeOH}-5 \mathrm{H}\right]^{+}$} & {$\left[\mathrm{C}_{21} \mathrm{H}_{13} \mathrm{Fe}_{2} \mathrm{~N}_{2} \mathrm{O}_{9}\right]^{+}$} & 548.9314 & 548.9315 & 0.15 \\
{$\left[4 \mathrm{XA}+2 \mathrm{Fe}{ }^{\mathrm{III}}-5 \mathrm{H}\right]^{+}$} & {$\left[\mathrm{C}_{40} \mathrm{H}_{23} \mathrm{Fe}_{2} \mathrm{~N}_{4} \mathrm{O}_{16}\right]^{+}$} & 926.9802 & 926.9806 & 0.35 \\
\hline
\end{tabular}




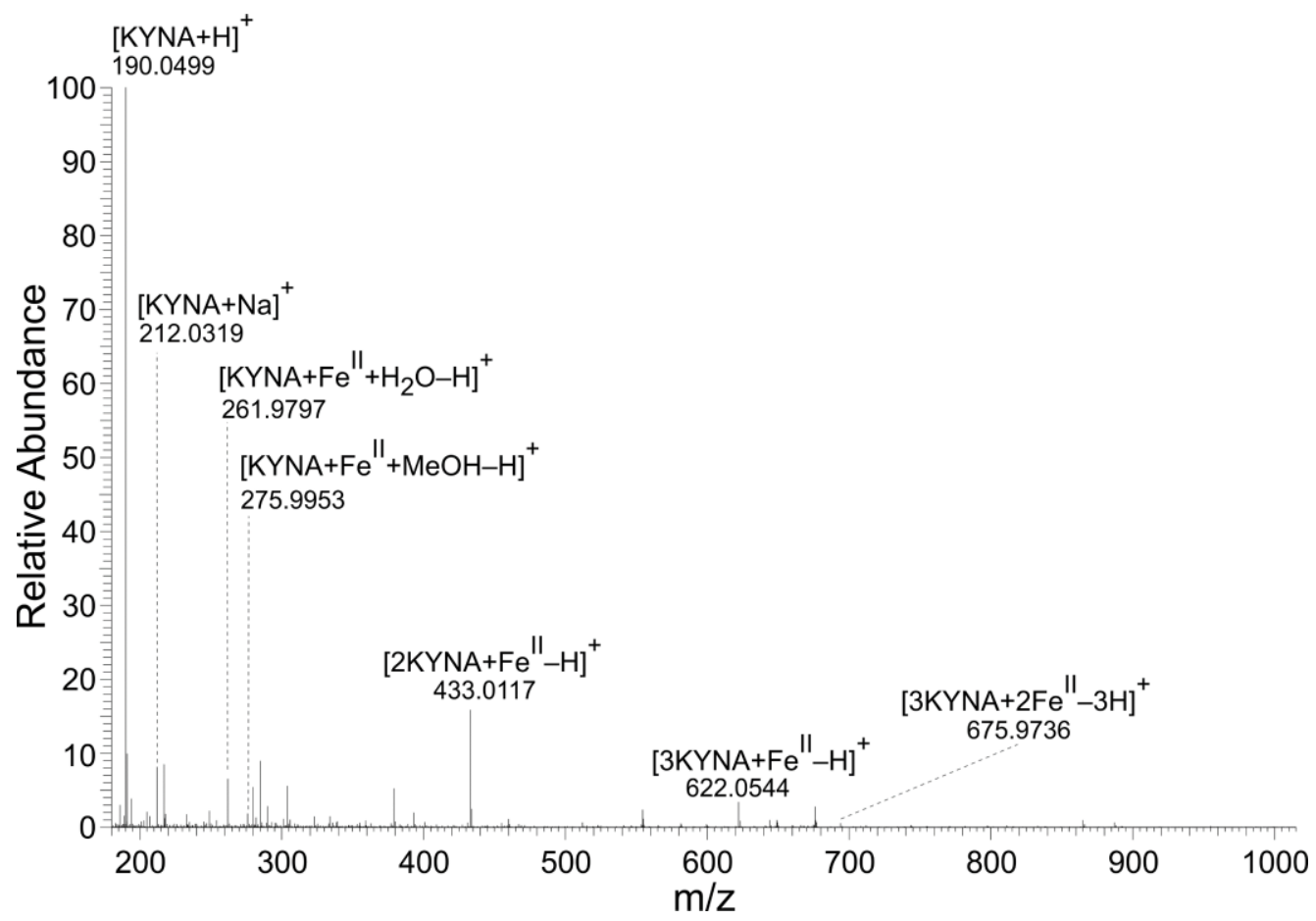

(a)

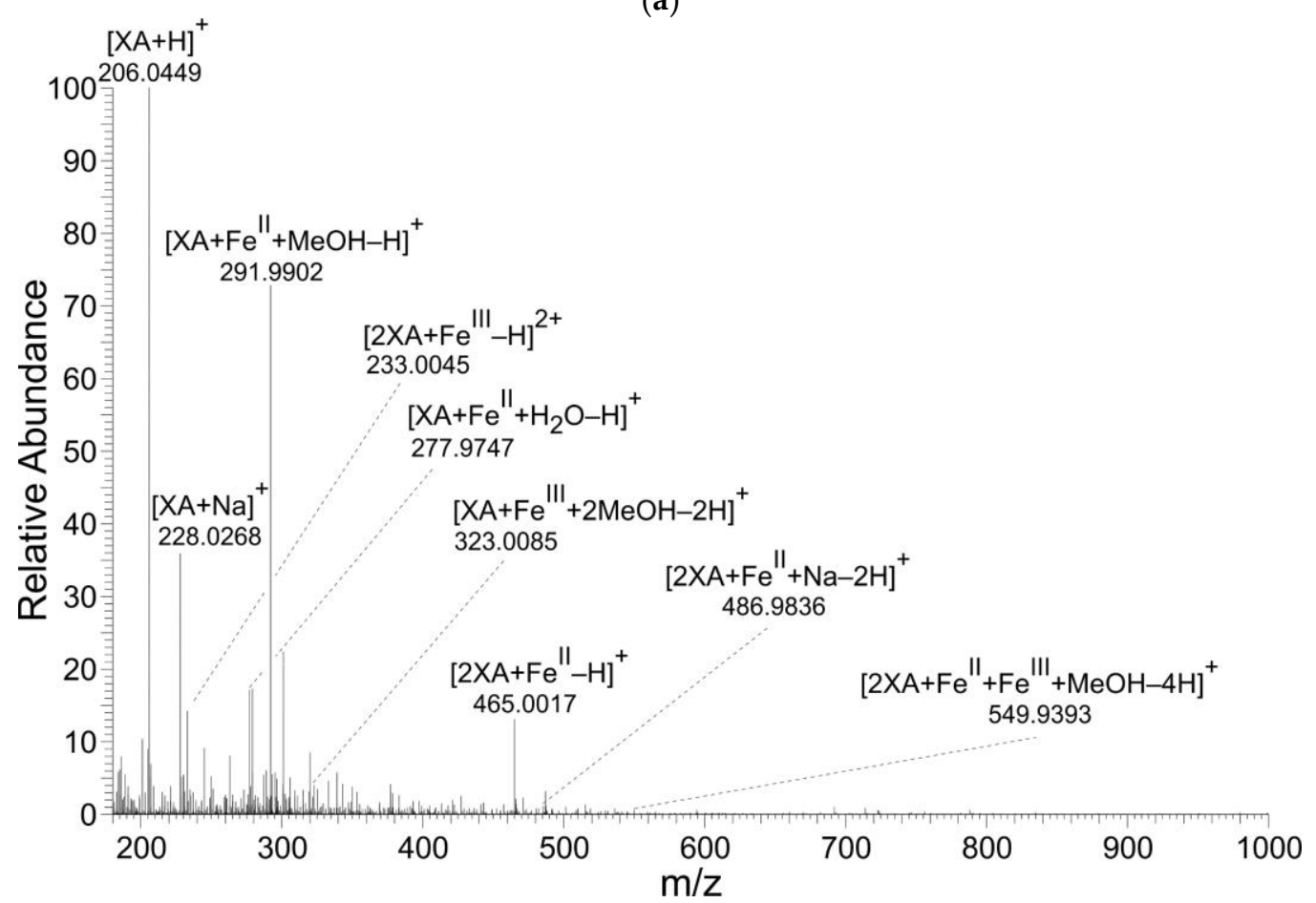

(b)

Figure 2. Cont. 


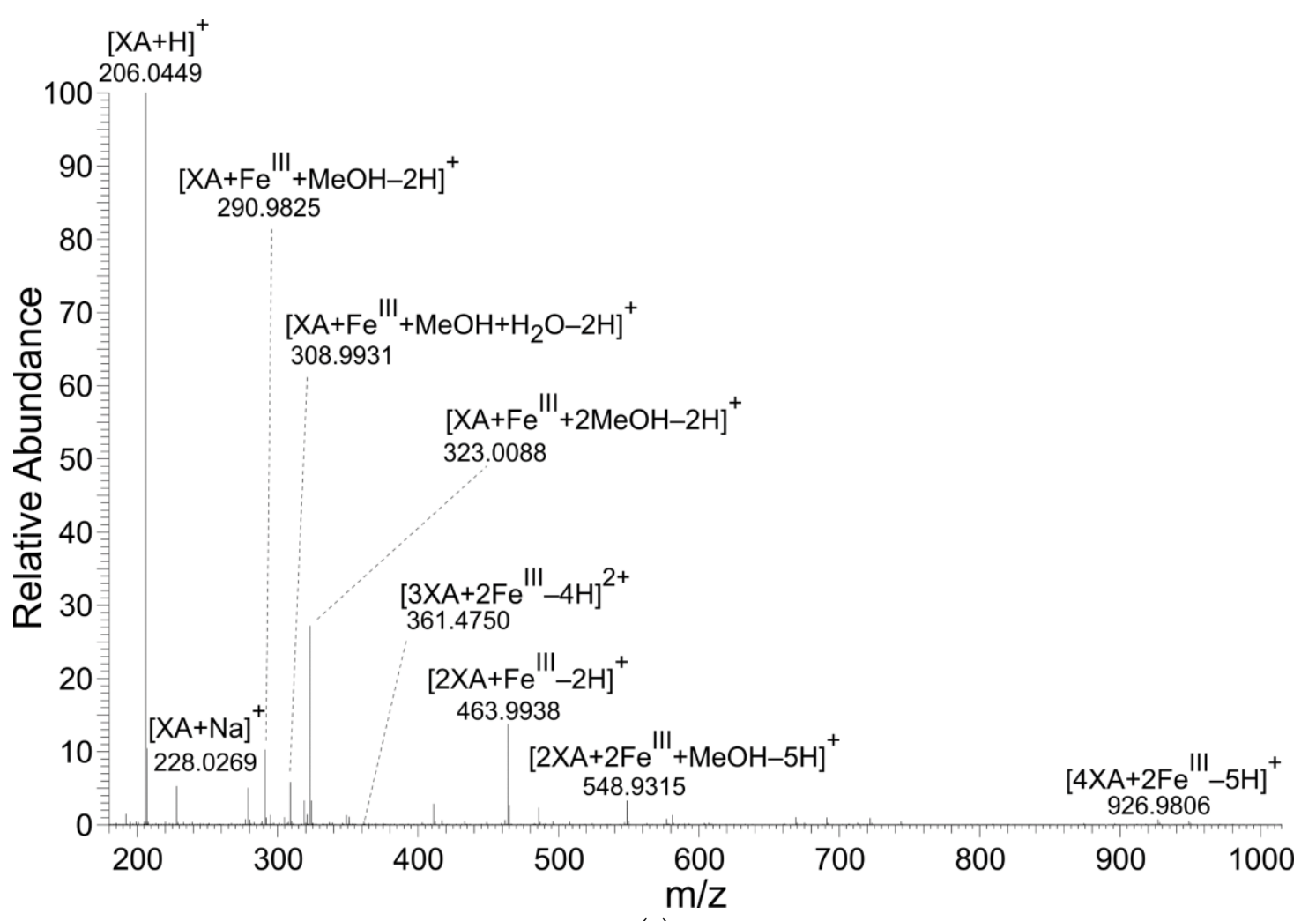

(c)

Figure 2. Mass spectra of coordination complexes in solutions of (a) $\mathrm{Fe}^{\mathrm{II}}$ with $\mathrm{KYNA}$, (b) $\mathrm{Fe}^{\mathrm{II}}$ with XA and (c) Fe $\mathrm{FII}^{\mathrm{III}}$ with $\mathrm{XA}$, detected by nano-ESI-MS, positive ionization mode. The solutions were prepared by mixing of the KYNA or XA solutions with $\mathrm{Fe}^{\mathrm{II}}$ or $\mathrm{Fe}^{\mathrm{III}}$ ions solutions in a molar ratio of metal to ligand of 1:2.

\subsection{Differential Pulse Voltammetry}

Both investigated acids proved electroactive (Figure 3). The XA voltammogram shows one prominent peak (XA 1) at the electrochemical potential of $501 \mathrm{mV}$ (Figure 3a). This signal corresponded probably with 8-hydroxy group oxidation [35].

In the voltammogram of KYNA, two peaks are visible at electrochemical potentials $1020 \mathrm{mV}$ (peak KYNA 1) and $1145 \mathrm{mV}$ (peak KYNA 2), respectively (Figure 3a). Peak KYNA 1 is relatively small and appears as a shoulder of the larger peak KYNA 2 that was a signal of 4-hydroxy group oxidation [36]. Nevertheless, the shapes of the oxidation peaks of both explored acids, KYNA and XA, indicate the complexity of the redox reactions. With high probability, the electrochemical reactions of the phenolic groups were followed by further chemical reactions [37].

Figure $3 \mathrm{~b}$ illustrates the voltammetric curves of pure $\mathrm{Fe}^{\mathrm{II}}$ solution, and mixture solutions of KYNA or XA with $\mathrm{Fe}^{\mathrm{II}}$ (ligand:metal 2:1 ratio). The $\mathrm{Fe}^{\mathrm{II}}$ curve shows two signals (peak $\mathrm{Fe}^{\mathrm{II}} 1$ at $-261 \mathrm{mV}$ and peak $\mathrm{Fe}^{\mathrm{II}} 2$ at $-69 \mathrm{mV}$ ). Additional weak peaks and shoulders were caused by mixtures of $\mathrm{Fe}^{\mathrm{II}}$ coordination complexes with phosphate anions and other components of the buffer as ligands.

The voltammogram of the XA:Fe ${ }^{\mathrm{II}}$ mixture solution exhibits the prominent apparently tailing peak $\mathrm{Fe}^{\mathrm{II}} 1$. Furthermore, the peak XA 1 corresponding to the 8-hydroxy group oxidation is evidently smaller compared to the peak of free XA.

The voltammogram of the KYNA:Fe ${ }^{\mathrm{II}}$ mixture solution differs dramatically from the curve of the free KYNA. The signal of 4-hydroxy group redox reaction at $1145 \mathrm{mV}$ (Figure 3, peak KYNA 2) almost disappears. In the voltammogram is saved only the small signal at $1062 \mathrm{mV}$, which is slightly shifted to the anodic direction in comparison to the free KYNA (Figure 3, peak KYNA 1 at $1020 \mathrm{mV}$ ). Furthermore, the peak of $\mathrm{Fe}^{\mathrm{II}}$ shows one broad tailing signal. 


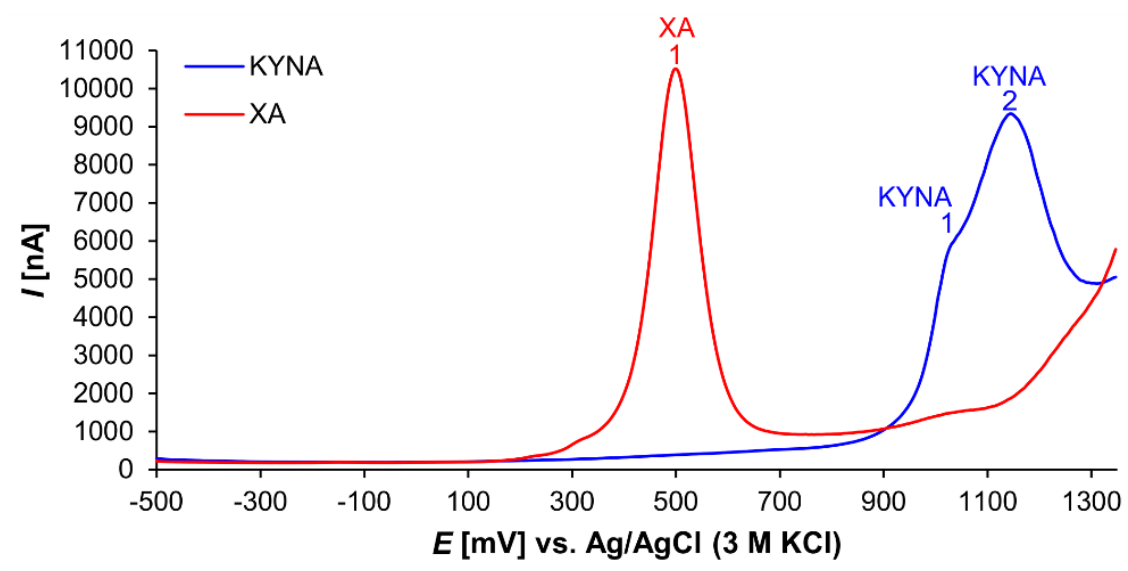

(a)

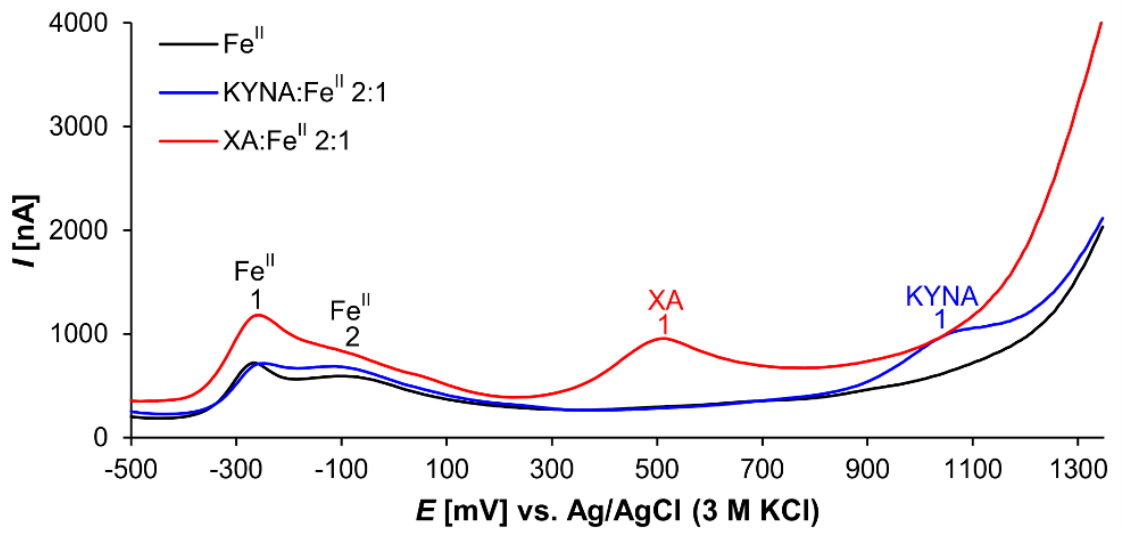

(b)

Figure 3. Differential pulse voltammograms of (a) KYNA or XA solutions and (b) solutions of $\mathrm{Fe}^{\mathrm{II}}$, 2:1 KYNA:Fe ${ }^{\mathrm{II}}$ or 2:1 XA:Fe $\mathrm{III}^{\mathrm{II}}$ mixtures.

\subsection{Deoxyribose Degradation Assay}

The deoxyribose degradation assay investigates possible interactions of test substances with hydroxyl radical production in an iron catalyzed Fenton-like reaction. The reaction mixture contained test substance, $\mathrm{H}_{2} \mathrm{O}_{2}, \mathrm{Fe}^{\mathrm{III}}$, ascorbic acid and 2-deoxyribose. The oxidation of 2-deoxyribose led to the production of thiobarbituric acid reactive species (TBARS). Ascorbic acid, a reducing agent, started the Fenton reaction by reduction of $\mathrm{Fe}^{\mathrm{III}}$ to $\mathrm{Fe}^{\mathrm{II}}$. Iron was added either as a coordination complex with ethylenediaminetetraacetic acid (EDTA) or as $\mathrm{FeCl}_{3}$, which can form complexes with the test compound. EDTA prevents coordination complex formation with a test substance as a ligand. The variants of deoxyribose degradation assay with presence of $\mathrm{H}_{2} \mathrm{O}_{2}$ simulated a situation of tissue damage with high ROS concentrations. The assay variants, where $\mathrm{H}_{2} \mathrm{O}_{2}$ and/or ascorbic acid were omitted, provided more extensive information about the redox chemistry of the test compounds [33].

Figure 4 shows that both acids demonstrated apparent antioxidant effects. However, in all investigated reaction mixtures, $\mathrm{XA}$ was a more efficient antioxidant than KYNA. In the reaction mixture containing $\mathrm{H}_{2} \mathrm{O}_{2} / \mathrm{FeCl}_{3}$ /ascorbic acid and $\mathrm{H}_{2} \mathrm{O}_{2} / \mathrm{Fe}^{\mathrm{III}}$ EDTA/ascorbic acid, the antioxidant activities were evident up to the concentration $16 \mu \mathrm{M}$ or $125 \mu \mathrm{M}$, respectively (Figure $4 \mathrm{a}, \mathrm{b}$ ). Coordination complex formation with either of the two quinoline acids enhanced antioxidant activity.

In the reaction mixtures missing $\mathrm{H}_{2} \mathrm{O}_{2}$, such as $\mathrm{FeCl}_{3}$ /ascorbic acid or $\mathrm{Fe}^{\mathrm{III}} \mathrm{EDTA} /$ ascorbic acid (Figure 4c,d), XA inhibited TBARS generation, a type of 2-deoxyribose degradation products, more effectively than KYNA. The different antioxidant activities of both acids are especially visible in the case of reaction mixture $\mathrm{FeCl}_{3}$ /ascorbic acid (Figure 4c), when KYNA could not prevent the oxidative degradation of 2-deoxyribose with the exception of the two highest tested concentrations. 
In the other variants of the deoxyribose degradation assay such as $\mathrm{H}_{2} \mathrm{O}_{2} / \mathrm{FeCl}_{3}, \mathrm{H}_{2} \mathrm{O}_{2} / \mathrm{Fe}^{\mathrm{III}}$ EDTA, $\mathrm{FeCl}_{3}$, and $\mathrm{Fe}^{\mathrm{III}} \mathrm{EDTA}$, no significant activities were observed (data not shown).

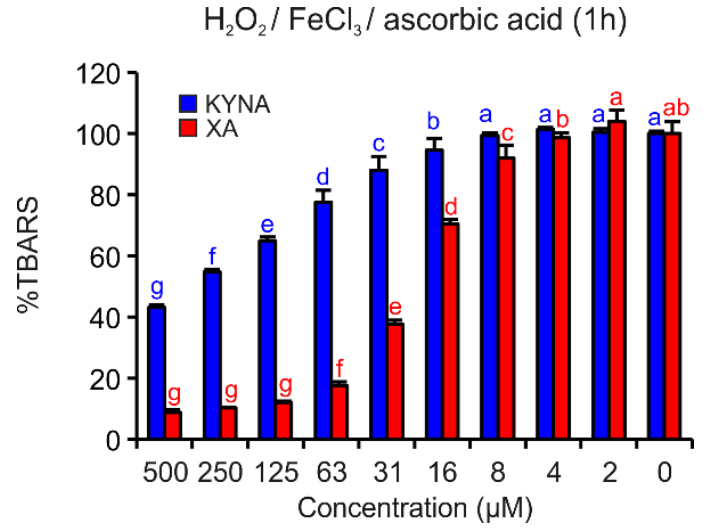

(a)

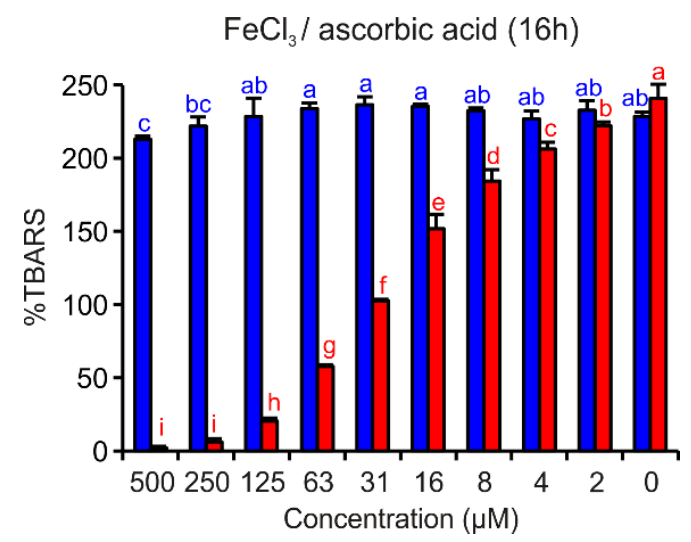

(c)

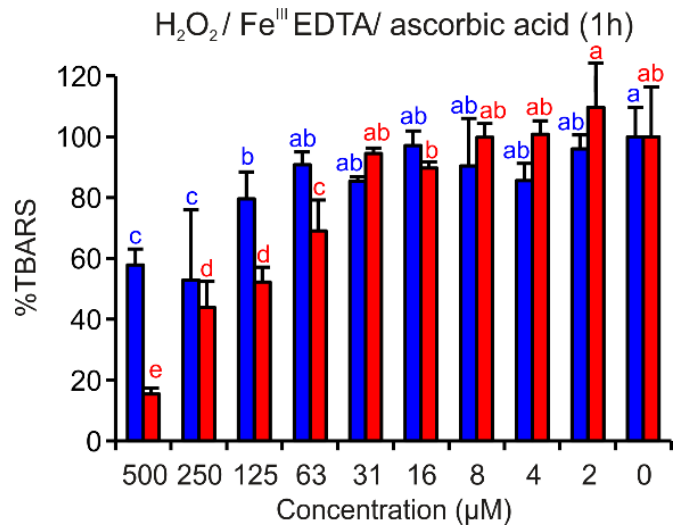

(b)

Fe"'EDTA/ ascorbic acid (16h)

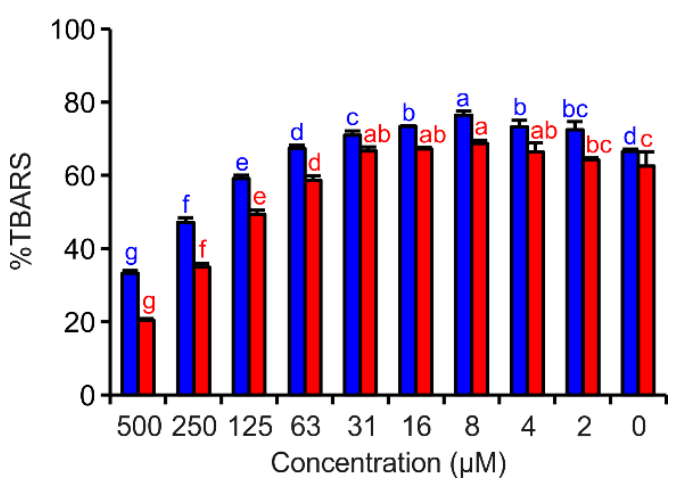

(d)

Figure 4. Inhibition effects of KYNA or XA on TBARS formation in the deoxyribose degradation assay: (a) $\mathrm{H}_{2} \mathrm{O}_{2} / \mathrm{FeCl}_{3} /$ ascorbic acid, (b) $\mathrm{H}_{2} \mathrm{O}_{2} / \mathrm{Fe}^{\mathrm{III}} \mathrm{EDTA} /$ ascorbic acid, (c) $\mathrm{FeCl}_{3}$ /ascorbic acid and (d) $\mathrm{Fe}^{\mathrm{III}}$ EDTA/ascorbic acid. The bars represent the mean of three replications ( \pm S.D.). Letters above the bars indicate significance levels (ANOVA with 95\% Duncan's post hoc test). TBARS: thiobarbituric acid reactive species, S.D.: standard deviation.

\subsection{Fe ${ }^{I I}$ Autoxidation Assay}

This assay extended the insights of deoxyribose degradation assay in terms of the capability of the test compound as ligand of $\mathrm{Fe}^{\mathrm{II}}$ central atom to scavenge or induce ROS during iron autoxidation and to affect $\mathrm{Fe}^{\mathrm{II}} / \mathrm{Fe}^{\mathrm{III}}$ redox cycling. In this assay, iron did not need to be reduced before participation in the Fenton reaction. Molecular oxygen that diffuses into reaction mixtures was reduced by $\mathrm{Fe}^{\mathrm{II}}$ to superoxide anion radical, which can spontaneously dismutate or be reduced to hydrogen peroxide. Then, hydrogen peroxide started the Fenton reaction and hydroxyl radical production. Hydroxyl radicals were detected as TBARS (2-deoxyribose decomposition products) [34].

In this assay, only XA exhibited significant antioxidant effects. By contrast, KYNA showed very weak pro-oxidant properties in the test concentrations of 16 and $31 \mu \mathrm{M}$ (Figure 5). 


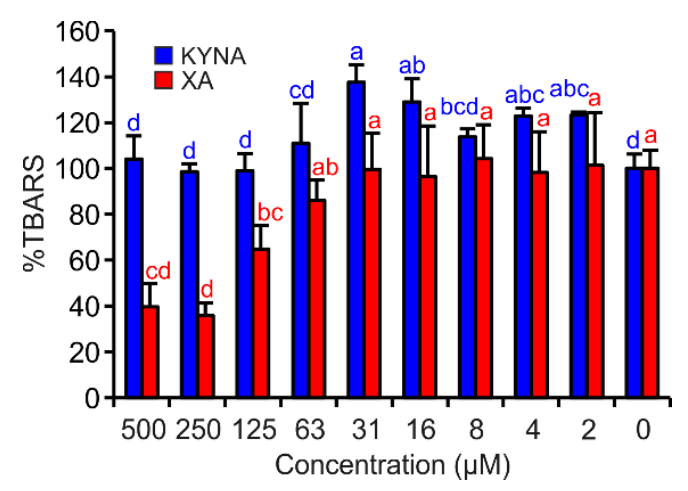

Figure 5. KYNA or XA effects on TBARS production in Fe $\mathrm{Fe}^{\mathrm{II}}$ autoxidation assay. The bars are the means of three replications ( \pm S.D.). Letters above the bars indicate significance levels (ANOVA with $95 \%$ Duncan's post hoc test). TBARS: thiobarbituric acid reactive species, S.D.: standard deviation.

\section{Discussion}

KYNA and XA represent endogenous redox active metabolites that can cause either pro- or antioxidant effects [5]. This specifically observed capability is determined by complex combinatory effects of ROS scavenging activities and inhibition of iron redox cycling, the latter of which is important for the ROS generation, especially the strongly oxidant hydroxyl radical, a product of the iron-catalysed Fenton reaction [38].

The mass spectrometry results corroborated KYNA's and XA's formation of Fe ion coordination complexes. However, only XA was liganded by both $\mathrm{Fe}^{\mathrm{II}}$ and $\mathrm{Fe}^{\mathrm{III}}$ forming mono or binuclear coordination complexes. In these binuclear coordination complexes, Fe was present either in the same or different valency stages. KYNA coordinated $\mathrm{Fe}^{\mathrm{II}}$ ions, also in mononuclear and binuclear complexes (Table 1, Figure 3a). However, no coordination complexes of KYNA with trivalent Fe ions were detected. Contrary to our results, Minakata et al. failed to detect Fe-KYNA coordination complexes spectrophotometrically [26].

The differential pulse voltammetry investigation corresponds the mass spectrometry results. The 8-hydroxy group present in XA substantially improves Fe liganding. The intensity of the 8-hydroxy group signal varied according to the Fe:XA ratio, a phenomenon that also became evident in a previously published electrochemical study on 8-hydroxyquinoline [39]. However, the peak absence of the KYNA 4-hydroxy group appeared to be independent of the Fe:KYNA concentration ratio.

Additionally, the voltammograms illustrate the anodic shift in the redox potentials of $\mathrm{Fe}$ coordination complexes with KYNA or XA in comparison to the free ligands and metal ions. In the presence of iron, the quinolines competed with the components of the phosphate buffer solution to ligand the central atom. Accordingly, $\mathrm{Fe}^{\mathrm{II}}$ atoms coordinating either KYNA or XA are more difficult to oxidize, whereas reduction of $\mathrm{Fe}^{\mathrm{III}}$ atoms in coordination complexes is easier.

The DPV (differential pulse voltammetry) results on the one hand, and the deoxyribose degradation and $\mathrm{Fe}^{\mathrm{II}}$ autoxidation assay results on the other hand, agree. In both assays, XA behaved as a potent antioxidant (Figures 4 and 5). These results suggest that XA's antioxidant effects depend on its ability to form coordination complexes with Fe ions (deoxyribose assay variants without EDTA, Figure 4a,c and $\mathrm{Fe}^{\mathrm{II}}$ autoxidation assay, Figure 5) and additionally on scavenging hydroxyl radicals (deoxyribose assay variants with EDTA, Figure 4b,d). Comparing XA with 8-hydroxyquinoline in terms of antioxidant activity in similar assays, XA was less efficient $[39,40]$. However, in contrast to the methodological approach of this study, Murakami et al. observed the pro-oxidant effects of XA [29]. Additionally, the results of this study point to the important contribution of the 8-hydroxy group to more pronounced antioxidant properties of XA. Moreover, the ROS scavenging effect of XA is supported by the conjugated and aromatic system that stabilizes the formed semiquinone radical [41].

An in vivo antioxidant study of XA proved that XA played a crucial role in tissue protection against Fe-induced cell death in female midguts of Aedes aegypti [42]. Furthermore, XA decreased Fe- 
or heme-catalysed lipid peroxidation and demonstrated a strong contribution of coordination complex formation with $\mathrm{Fe}^{\mathrm{II}}$ ions to alleviating oxidative damage. A previous study supports the present observations by also reporting the mitigating effects of XA on metal-catalysed lipid peroxidation [27]. Additionally and in accordance, a mosquito strain, which is only able to produce KYNA in its midgut, proved to be less efficiently protected against Fe-induced tissue damage [42].

Compared to XA, KYNA proved to be not antioxidant in the $\mathrm{FeCl}_{3}$ /ascorbic acid deoxyribose degradation assay variant (Figure 4c) and showed only negligible activities in $\mathrm{Fe}^{\mathrm{II}}$ autoxidation assay (Figure 5). In both cases, KYNA had the opportunity to form coordination complexes with Fe ions. KYNA was not able to prevent the reduction of molecular oxygen to superoxide anion radical and consequent TBARS generation. It is possible that Fe-KYNA coordination complexes increase the dismutation rate of superoxide anion radical to hydrogen peroxide. Mahal et al. reported comparable catalytic effects on superoxide anion radical dismutation of Fe coordination complexes with phenols and aminophenols [43]. These observations also correspond well to those reported by Murakami et al., who observed no effects of KYNA on $\mathrm{Fe}^{\mathrm{II}}$ autoxidation-induced lipid peroxidation [27]. Probably, KYNA inhibits 2-deoxyribose oxidative degradation primarily by hydroxyl radical scavenging, which corresponds to the effects that are visible in the full reaction mixture of the deoxyribose degradation assay (Figure 4a,b). Lugo-Lutron et al., who investigated KYNA antioxidant properties by a set of assays, including the $\mathrm{H}_{2} \mathrm{O}_{2} / \mathrm{Fe}^{\mathrm{III}} \mathrm{EDTA} /$ ascorbic acid variant of deoxyribose degradation assay, obtained similar results [25]. In other types of antioxidant assays, KYNA showed no or only weak antioxidant activity $[25,26]$. Generally, KYNA acts as an antioxidant in higher concentrations than XA. However, some KYNA chemical derivatives are more efficient in passing the BBB and become metabolized to KYNA afterwards [44].

In the deoxyribose degradation assay variants, where ascorbic acid was omitted, neither KYNA nor XA was able to substitute ascorbic acid function and to reduce $\mathrm{Fe}^{\mathrm{III}}$ to $\mathrm{Fe}^{\mathrm{II}}$. Thus, consequently, the Fenton reaction could not be started. Therefore, no activities were observed in these four deoxyribose degradation assay variants (data not shown).

The DPV of Fe-KYNA coordination complexes lack an oxidation peak of the 4-hydroxy group. A possible reason for this may be the formation of the more stable KYNA keto tautomer (Figure 6) in the coordination complexes with $\mathrm{Fe}^{\mathrm{II}}$. The peak KYNA 1 in the DPV probably corresponds to the oxidation of heterocyclic $\mathrm{NH}$ group at position 1.

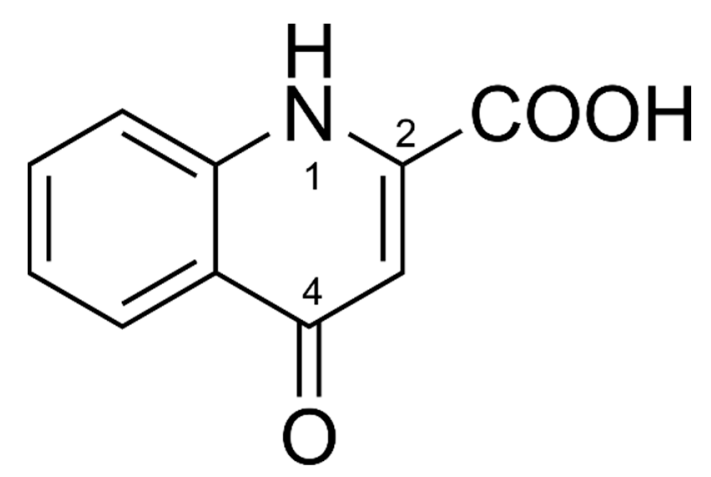

Figure 6. Chemical structure of KYNA keto tautomer.

\section{Conclusions}

The chemical properties of KYNA and XA provide evidence that both acids can affect brain tissues by interactions with various receptors and further by pre-receptor chemistry. They contribute to the maintenance of redox and iron homeodynamics when mitochondria become damaged and the permeability of the blood-brain barrier is increased. Damaged mitochondria and the blood-brain barrier are often associated with neurodegenerative diseases. Therefore, modulation of KYNA and 
XA concentrations in the brain represent a promising therapeutic approach to retard the cognitive disfunction development of patients that suffer from Alzheimer's or Parkinson's diseases.

Author Contributions: Conceptualization, V.C. and L.K.; Methodology, V.C. and L.K.; Formal analysis, V.C., F.H., G.B. and L.K.; Investigation, V.C. and L.K.; Resources, W.W.; Data curation, V.C. and L.K.; Writing-original draft preparation, V.C., F.H. and L.K.; Writing-review and editing, V.C., F.H., G.B., L.K. and W.W.; Visualization, V.C. and L.K.; Project administration, V.C., G.B. and L.K.; Funding acquisition, V.C., F.H. and W.W.

Funding: This research was funded by Austrian Science Fund (FWF), grant number P 24630-B21.

Conflicts of Interest: The authors declare no conflict of interest. The funders had no role in the design of the study; in the collection, analyses, or interpretation of data; in the writing of the manuscript, or in the decision to publish the results.

\section{Abbreviations}

$\begin{array}{ll}\text { BBB } & \text { Blood-brain barrier } \\ \text { DNA } & \text { Deoxyribonucleic acid } \\ \text { DPV } & \text { Differential pulse voltammetry } \\ \text { EDTA } & \text { Ethylenediaminetetraacetic acid } \\ \text { KYNA } & \text { Kynurenic acid } \\ \text { Nano-ESI-MS } & \text { Nano-electrospray-mass spectrometry } \\ \text { ROS } & \text { Reactive oxygen species } \\ \text { S.D. } & \text { Standard deviation } \\ \text { TBARS } & \text { Thiobarbituric acid reactive species } \\ \text { XA } & \text { Xanthurenic acid }\end{array}$

\section{References}

1. Graves, D.B. The emerging role of reactive oxygen and nitrogen species in redox biology and some implications for plasma applications to medicine and biology. J. Phys. D Appl. Phys. 2012, 45, 263001. [CrossRef]

2. Nordzieke, D.E.; Medraño-Fernandez, I. The plasma membrane: A platform for intra- and intercellular redox signaling. Antioxidants 2018, 7, 168. [CrossRef] [PubMed]

3. Hörandl, E.; Hadacek, F. The oxidative damage initiation hypothesis for meiosis. Plant Reprod. 2013, 26, 351-367. [CrossRef] [PubMed]

4. Hadacek, F.; Bachmann, G. Low-molecular-weight metabolite systems chemistry. Front. Environ. Sci. 2015, 3, 12. [CrossRef]

5. Esquivel, D.G.; Ramirez-Ortega, D.; Pineda, B.; Castro, N.; Rios, C.; de la Cruz, V. Kynurenine pathway metabolites and enzymes involved in redox reactions. Neuropharmacology 2017, 112, 331-345. [CrossRef] [PubMed]

6. Schwarcz, R.; Stone, T.W. The kynurenine pathway and the brain: Challenges, controversies and promises. Neuropharmacology 2017, 112, 237-247. [CrossRef] [PubMed]

7. Erhardt, S.; Schwieler, L.; Imbeault, S.; Engberg, G. The kynurenine pathway in schizophrenia and bipolar disorder. Neuropharmacology 2017, 112, 297-306. [CrossRef] [PubMed]

8. Lovelace, M.D.; Varney, B.; Sundaram, G.; Lennon, M.J.; Lim, C.K.; Jacobs, K.; Guillemin, G.J.; Brew, B.J. Recent evidence for an expanded role of the kynurenine pathway of tryptophan metabolism in neurological diseases. Neuropharmacology 2017, 112, 373-388. [CrossRef] [PubMed]

9. Wirthgen, E.; Hoeflich, A.; Rebl, A.; Gunther, J. Kynurenic acid: The Janus-faced role of an immunomodulatory tryptophan metabolite and its link to pathological conditions. Front. Immunol. 2017, 8, 1957. [CrossRef] [PubMed]

10. Fazio, F.; Lionetto, L.; Curto, M.; Iacovelli, L.; Copeland, C.S.; Neale, S.A.; Bruno, V.; Battaglia, G.; Salt, T.E.; Nicoletti, F. Cinnabarinic acid and xanthurenic acid: Two kynurenine metabolites that interact with metabotropic glutamate receptors. Neuropharmacology 2017, 112, 365-372. [CrossRef] [PubMed]

11. Tan, L.; Yu, J.T. The kynurenine pathway in neurodegenerative diseases: Mechanistic and therapeutic considerations. J. Neurol. Sci. 2012, 323, 1-8. [CrossRef] [PubMed] 
12. Majewski, M.; Kozlowska, A.; Thoene, M.; Lepiarczyk, E.; Grzegorzewski, W.J. Overview of the role of vitamins and minerals on the kynurenine pathway in health and disease. J. Physiol. Pharmacol. 2016, 67, 3-19. [PubMed]

13. Colin-Gonzalez, A.L.; Maldonado, P.D.; Santamaria, A. 3-Hydroxykynurenine: An intriguing molecule exerting dual actions in the central nervous system. Neurotoxicology 2013, 34, 189-204. [CrossRef] [PubMed]

14. Moroni, F.; Russi, P.; Lombardi, G.; Beni, M.; Carla, V. Presence of kynurenic acid in the mammalian brain. J. Neurochem. 1988, 51, 177-180. [CrossRef] [PubMed]

15. Moroni, F.; Cozzi, A.; Sili, M.; Mannaioni, G. Kynurenic acid: A metabolite with multiple actions and multiple targets in brain and periphery. J. Neural. Transm. 2012, 119, 133-139. [CrossRef] [PubMed]

16. Turski, M.P.; Kaminski, P.; Zgrajka, W.; Turska, M.; Turski, W.A. Potato- An important source of nutritional kynurenic acid. Plant Food Hum. Nutr. 2012, 67, 17-23. [CrossRef]

17. Dehhaghi, M.; Kazemi Shariat Panahi, H.; Guillemin, G.J. Microorganisms, tryptophan metabolism, and kynurenine pathway: A complex interconnected loop influencing human health status. Int. J. Tryptophan. Res. 2019, 12, 1178646919852996. [CrossRef]

18. Kennedy, P.J.; Cryan, J.F.; Dinan, T.G.; Clarke, G. Kynurenine pathway metabolism and the microbiota-gut-brain axis. Neuropharmacology 2017, 112, 399-412. [CrossRef]

19. Datki, Z.; Galik-Olah, Z.; Bohar, Z.; Zadori, D.; Fulop, F.; Szatmari, I.; Galik, B.; Kalman, J.; Vecsei, L. Kynurenic acid and its analogs are beneficial physiologic attenuators in bdelloid rotifers. Molecules 2019, 24, 2171. [CrossRef]

20. Montagne, A.; Zhao, Z.; Zlokovic, B.V. Alzheimer's disease: A matter of blood-brain barrier dysfunction? J. Exp. Med. 2017, 214, 3151-3169. [CrossRef]

21. Pretorius, L.; Kell, D.B.; Pretorius, E. Iron dysregulation and dormant microbes as causative agents for impaired blood rheology and pathological clotting in Alzheimer's type dementia. Front. Neurosci. 2018, 12, 851. [CrossRef] [PubMed]

22. Kell, D.B. Iron behaving badly: Inappropriate iron chelation as a major contributor to the aetiology of vascular and other progressive inflammatory and degenerative diseases. BMC Med. Genom. 2009, 2, 2. [CrossRef] [PubMed]

23. Kell, D.B. Towards a unifying, systems biology understanding of large-scale cellular death and destruction caused by poorly liganded iron: Parkinson's, Huntington's, Alzheimer's, prions, bactericides, chemical toxicology and others as examples. Arch. Toxicol. 2010, 84, 825-889. [CrossRef] [PubMed]

24. Lovell, M.A.; Robertson, J.D.; Teesdale, W.J.; Campbell, J.L.; Markesbery, W.R. Copper, iron and zinc in Alzheimer's disease senile plaques. J. Neurol. Sci. 1998, 158, 47-52. [CrossRef]

25. Lugo-Huitron, R.; Blanco-Ayala, T.; Ugalde-Muniz, P.; Carrillo-Mora, P.; Pedraza-Chaverri, J.; Silva-Adaya, D.; Maldonado, P.D.; Torres, I.; Pinzon, E.; Ortiz-Islas, E.; et al. On the antioxidant properties of kynurenic acid: Free radical scavenging activity and inhibition of oxidative stress. Neurotoxicol. Teratol. 2011, 33, 538-547. [CrossRef]

26. Minakata, K.; Fukushima, K.; Nakamura, M.; Iwahashi, H. Effect of some naturally occurring iron ion chelators on the formation of radicals in the reaction mixtures of rat liver microsomes with ADP, Fe and NADPH. J. Clin. Biochem. Nutr. 2011, 49, 207-215. [CrossRef] [PubMed]

27. Murakami, K.; Ito, M.; Yoshino, M. Xanthurenic acid inhibits metal ion-induced lipid peroxidation and protects NADP-isocitrate dehydrogenase from oxidative inactivation. J. Nutr. Sci. Vitaminol. 2001, 47, 306-310. [CrossRef]

28. Lopez-Burillo, S.; Tan, D.X.; Mayo, J.C.; Sainz, R.M.; Manchester, L.C.; Reiter, R.J. Melatonin, xanthurenic acid, resveratrol, EGCG, vitamin $\mathrm{C}$ and $\alpha$-lipoic acid differentially reduce oxidative DNA damage induced by Fenton reagents: A study of their individual and synergistic actions. J. Pineal Res. 2003, 34, 269-277. [CrossRef]

29. Murakami, K.; Haneda, M.; Yoshino, M. Prooxidant action of xanthurenic acid and quinoline compounds: Role of transition metals in the generation of reactive oxygen species and enhanced formation of 8-hydroxy-2'-deoxyguanosine in DNA. Biometals 2006, 19, 429-435. [CrossRef]

30. Chobot, V.; Hadacek, F.; Weckwerth, W.; Kubicova, L. Iron chelation and redox chemistry of anthranilic acid and 3-hydroxyanthranilic acid: A comparison of two structurally related kynurenine pathway metabolites to obtain improved insights into their potential role in neurological disease development. J. Organomet. Chem. 2015, 782, 103-110. [CrossRef] 
31. Kubicova, L.; Hadacek, F.; Chobot, V. Quinolinic Acid: Neurotoxin or oxidative stress modulator? Int. J. Mol. Sci. 2013, 14, 21328-21338. [CrossRef] [PubMed]

32. Kubicova, L.; Hadacek, F.; Weckwerth, W.; Chobot, V. Effects of endogenous neurotoxin quinolinic acid on reactive oxygen species production by Fenton reaction catalyzed by iron or copper. J. Organomet. Chem. 2015, 782, 111-115. [CrossRef] [PubMed]

33. Chobot, V. Simultaneous detection of pro- and antioxidative effects in the variants of the deoxyribose degradation assay. J. Agric. Food Chem. 2010, 58, 2088-2094. [CrossRef]

34. Chobot, V.; Hadacek, F.; Kubicova, L. Effects of selected dietary secondary metabolites on reactive oxygen species production caused by iron(II) autoxidation. Molecules 2014, 19, 20023-20033. [CrossRef] [PubMed]

35. Stevic, M.C.; Ignjatovic, L.M.; Ciric-Marjanovic, G.; Stanisic, S.M.; Stankovic, D.M.; Zima, J. Voltammetric behaviour and determination of 8-hydroxyquinoline using a glassy carbon paste electrode and the theoretical study of its electrochemical oxidation mechanism. Int. J. Electrochem. Sci. 2011, 6, 2509-2525.

36. Giles, G.I.; Collins, C.A.; Stone, T.W.; Jacob, C. Electrochemical and in vitro evaluation of the redox-properties of kynurenine species. Biochem. Biophys. Res. Commun. 2003, 300, 719-724. [CrossRef]

37. Bard, A.J.; Faulkner, L.R. Electrochemical Methods: Fundamentals and Applications, 2nd ed.; John Wiley \& Sons, Inc.: New York, NY, USA, 2001; pp. 471-528.

38. Koppenol, W.H.; Hider, R.H. Iron and redox cycling. Do's and don'ts. Free Radical Biol. Med. 2019, 133 , 3-10. [CrossRef] [PubMed]

39. Chobot, V.; Hadacek, F.; Bachmann, G.; Weckwerth, W.; Kubicova, L. Antioxidant properties and the formation of iron coordination complexes of 8-hydroxyquinoline. Int. J. Mol. Sci. 2018, 19, 3917. [CrossRef]

40. Chobot, V.; Drage, S.; Hadacek, F. Redox properties of 8-quinolinol and implications for its mode of action. Nat. Prod. Commun. 2011, 6, 597-602. [CrossRef]

41. Rice-Evans, C.A.; Miller, N.J.; Paganga, G. Structure-antioxidant activity relationships of flavonoids and phenolic acids. Free Radical Biol. Med. 1996, 20, 933-956. [CrossRef]

42. Lima, V.L.A.; Dias, F.; Nunes, R.D.; Pereira, L.O.; Santos, T.S.R.; Chiarini, L.B.; Ramos, T.D.; Silva-Mendes, B.J.; Perales, J.; Valente, R.H.; et al. The antioxidant role of xanthurenic acid in the Aedes aegypti midgut during digestion of a blood meal. PLoS ONE 2012, 7, e38349. [CrossRef]

43. Mahal, H.S.; Kapoor, S.; Satpati, A.K.; Mukherjee, T. Radical scavenging and catalytic activity of metal-phenolic complexes. J. Phys. Chem. B 2005, 109, 24197-24202. [CrossRef]

44. Stone, T.W. Development and therapeutic potential of kynurenic acid and kynurenine derivatives for neuroprotection. Trends Pharmacol. Sci. 2000, 21, 149-154. [CrossRef] 